\title{
Histology of pseudobranchial tumours in Atlantic cod (Gadus morhua) from the North Sea and the Baltic Sea
}

\author{
B. Watermann ${ }^{1,2} \&$ V. Dethlefsen ${ }^{1}$ \\ 1 Bundesforschungsanstalt für Fischerei, Institut für Küsten- und Binnenfischerei, \\ Toxikologisches Laboratorium Cuxhaven; Niedersachsenstraße, 2190 Cuxhaven, \\ Federal Republic of Germany \\ 2 Zoologisches Institut der Universität Hamburg; Martin-Luther-King-Platz 3, \\ 2000 Hamburg 13, Federal Republic of Germany
}

\begin{abstract}
Atlantic cod bearing pseudobranchial tumours were investigated from both North Sea and Baltic Sea areas. Light and electron microscopic studies revealed a tumorous structure previously described in cod from Atlantic and Pacific waters. Additionally, cysts, multinucleated cells and early stages of mitosis are described.These findings support the hypothesis that pseudobranchial tumours are instigated by a protozoan infection causing xenotumours associated with the pseudobranch organ. The cells contained in these lesions showed similarities to amoebae.
\end{abstract}

\section{INTRODUCTION}

There is a paucity of reports of pseudobranchial tumours in Atlantic cod. Overall, it is still unclear whether these tumours are neoplastic cells resembling other endocrine tumours, or virally transformed cells or xenomas produced by the invasion of unicellular organisms. Peyron \& Thomas (1929) described two cases of this condition in cod from the French coast and concluded analogies to endocrine tumours in mammals. Lange (1973) and Lange \& Johannessen (1977) investigated several cases from Norwegian waters, and called the tumours chemodectoma. Morrison et al. (1979) found an infection rate of $1.1 \%$ in cod from Atlantic waters near the Scotian Banks but made no conclusion about the character of the lesion. Egidius et al. (1981) reported pseudobranchial tumours from the Barents Sea with the same histopathological features described in detail by Lange \& Johannessen (1977). This report presents histological descriptions of pseudobranchial tumours in cod.

\section{MATERIAL AND METHODS}

Cod were sampled from the North Sea during cruises with RV "Anton Dohrn" in January and July 1979, January, February and June 1980 and January, May and June 1981. Sampling stations were distributed over a wide area of the German Bight including the dumping sites of sewage sludge and wastes from $\mathrm{TiO}_{2}$ production. In addition, samples were collected in Dutch coastal areas and on the Dogger Bank. Samples from the western Baltic Sea were obtained in October 1980 from a cruise of RV "Solea". 
For light microscopy, the tumours were fixed in $10 \%$ buffered formalin and embedded in paraffin wax and sections cut at $6 \mu \mathrm{m}$. For electron microscopy, material was fixed in $6 \%$ phosphate buffered glutaraldehyde and embedded in Epon. The paraffin sections were stained with eosin and haematoxylin using Heidenhein's azan method. Semi-thin Epon sections $(1-2 \mu \mathrm{m})$ were stained with toluidine-blue, and ultrathin sections for electron microscopy were stained with lead citrate, uranyl acetate and phosphotungstic acid.

\section{RESULTS}

Cod with pseudobranchial tumours were generally in good condition apart from the smallest fish in each year class, where a small number of fish were emaciated. Internal organs showed no abnormalities with the exception of one $80 \mathrm{~m}$ long cod, which revealed complete gonadal atrophy.

The tumours were mainly associated with the pseudobranch organ, occurring both bilaterally and symmetrically (Fig. 1) and seldom unilaterally (Fig. 2). Additionally,

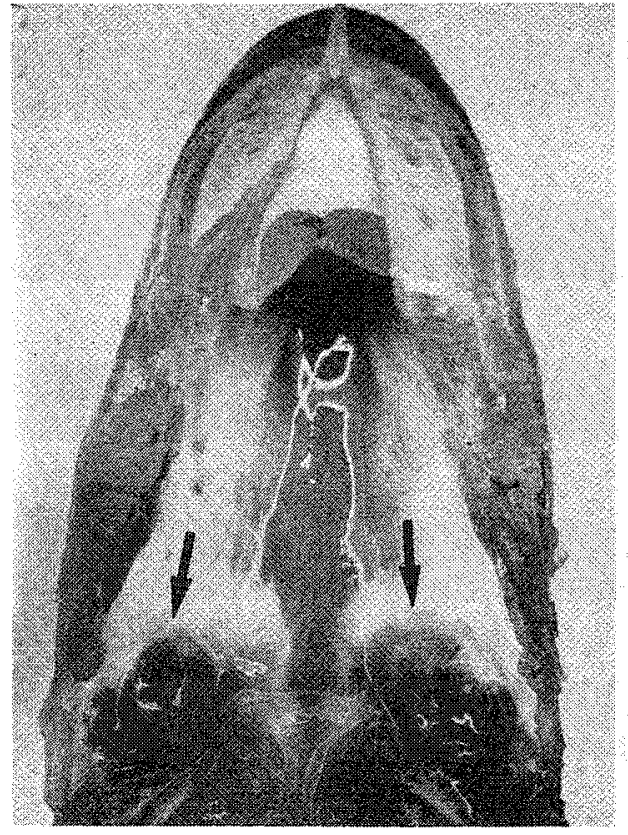

Fig. 1

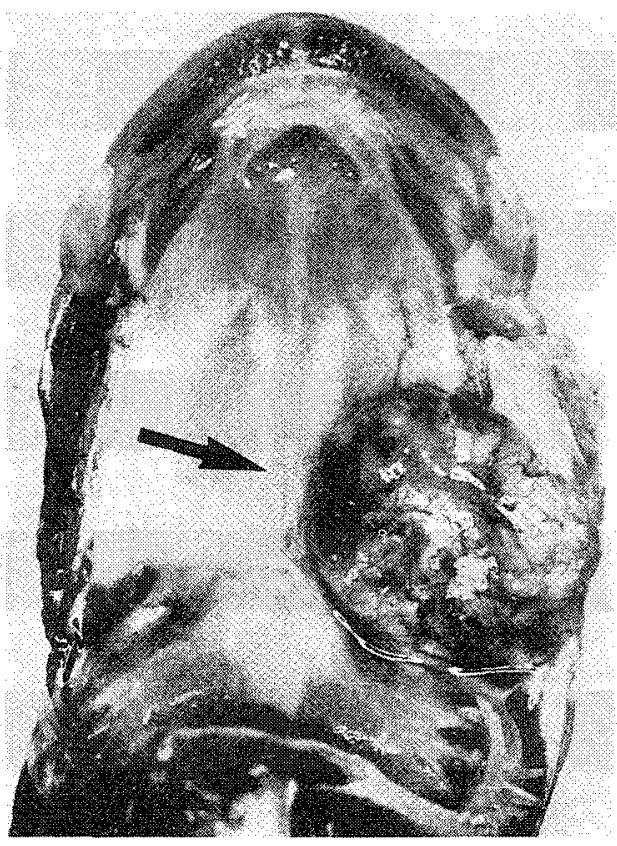

Fig. 2

Fig. 1. Early bilateral stage of pseudobranchial tumour with reddish to yellow appearance. Arrows indicating the lesions. Half the natural size

Fig. 2. Unilateral large tumour with yellow to whitish appearance. Arrow indicating the lesion. Half the natural size 
about $50 \%$ of the affected cod showed tumorous growth on the dorsolateral edge of the operculum, equally occurring uni - or bilaterally. Single tumours could be found in several regions on the head, for example around the nose, under the dental plate attached to the inner side of the operculum, and numerous small tumours, each about $1 \mathrm{~mm}^{3}$, were found along the gill arches, attached to the lamellae.

Most of the lesions were covered with normal epidermis. But those tumours associated with the pseudobranch organ, the convoluted rudimentary gill filaments and the gill capsule were partly destroyed. The pseudobranch cells appeared swollen, separating from the gill lamellae.

Early tumour stages appeared in the pseudobranch organ as slight swellings, which were often reddish or dark red (Fig. 1) with a smooth consistency and a tendency to liquifaction. This latter characteristic was typical of pseudobranchial tumours in Baltic Sea cod.

The general microscopical appearance of the tumours was characterized by the presence of "X-cells". These were large cells with pale nuclei and prominent nucleoli. On the periphery or between the fibrous septae, the cytoplasm of the "X-cells" was densely granular, whereas " $\mathrm{X}$-cells" in the central parts of the tumours and near the fibrous septae had cytoplasm which was clear and highly vacuolated. Peripherally placed "X-cells" were surrounded by slim "envelope-cells"; however, many of the centrally located cells appeared to be floating in the interstitial fluid, displaying amoeboid shapes. "X-cells" from Baltic Sea cod showed stages of degradation, and

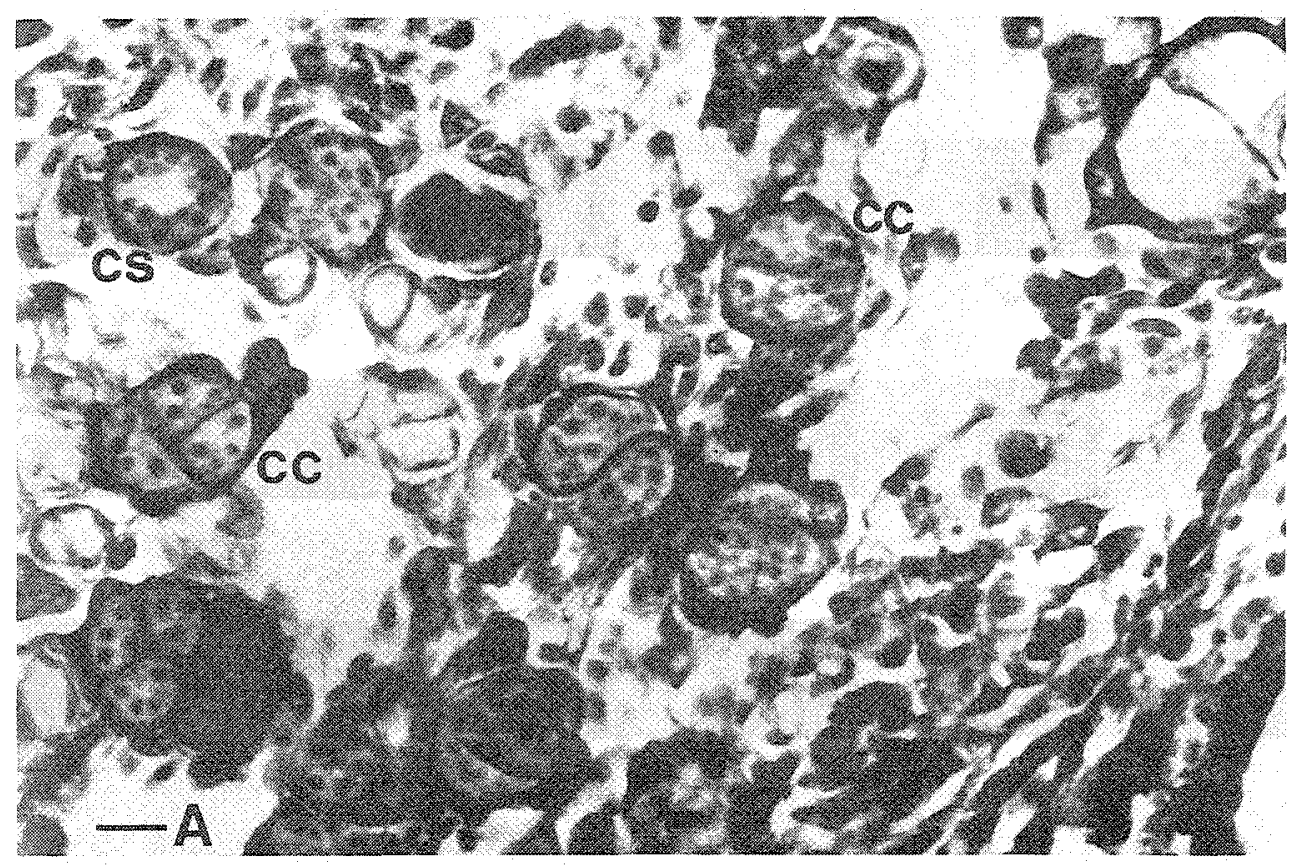

Fig. 3. Cysts in the pseudobranch organ subdivided in several compartments or with nuclei in a sphere arrangement. $\mathrm{cc}=$ Subdivided $\mathrm{cysts}, \mathrm{cs}=$ cyst with nuclei in a sphere arrangement, $\mathrm{A}=$ $10 \mu \mathrm{m}$, Azan stained 
When the tumours were incised, the cells leaked leaving only the fibrous septae behind. The ultra-structure of the "X-cells" revealed finely dispersed chromatin distributed evenly throughout the nucleus, plus a prominent nucleolus. The cytoplasm contained numerous membrane-bound granules, which corresponded to the granules seen in light microscopy. Mitochondria appeared tubular and poorly developed.

\section{Cysts and multinucleated stages}

Slight swellings near the pseudobranch organ showed features differing from those of typical pseudobranchial tumours. The difference consisted in the occurrence of cysts and multinucleated cells situated on the periphery of the lesions. The only similarity with the regular pseudobranchial tumours was the presence of " $\mathrm{X}$-cells" in the central areas.

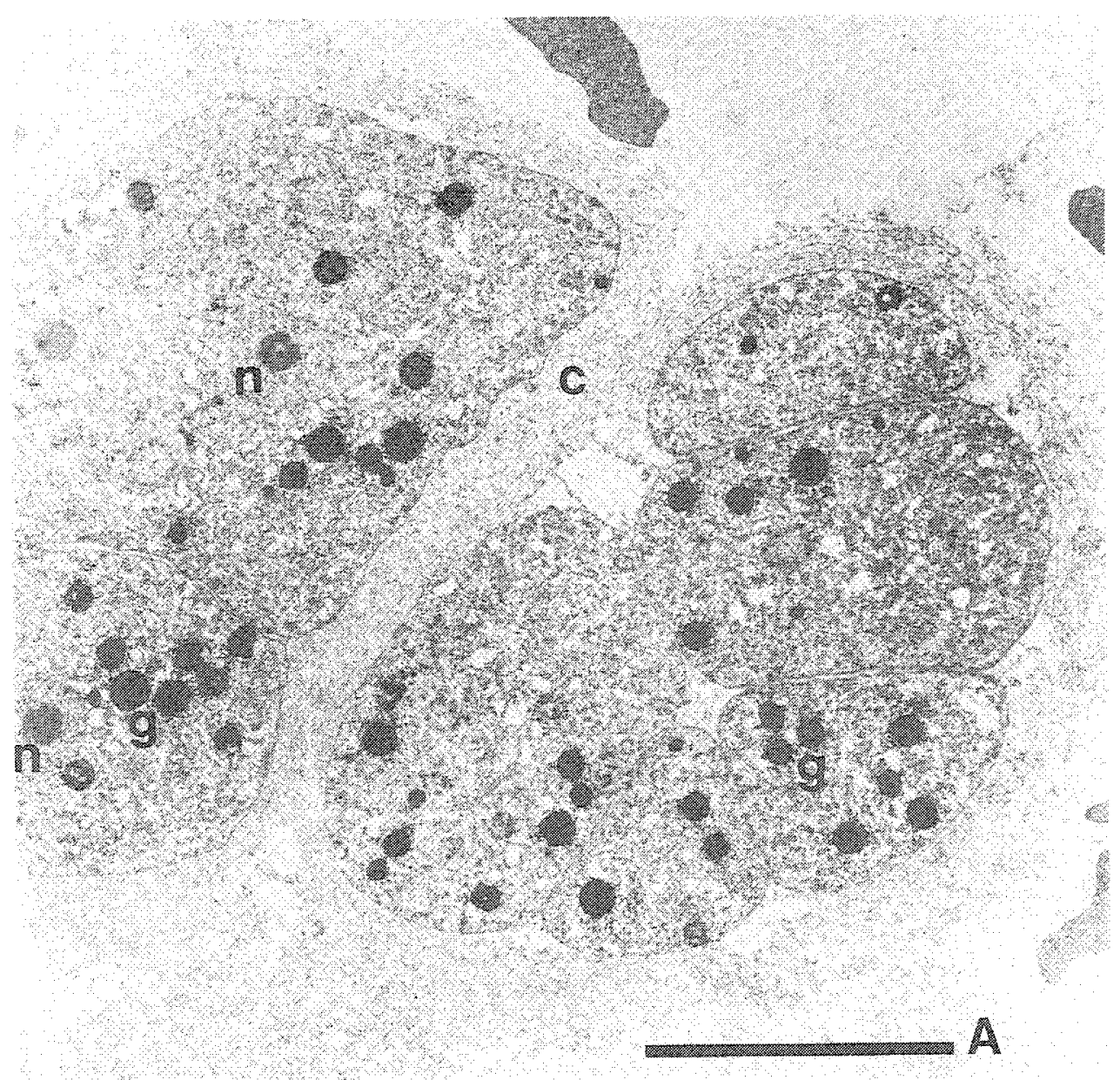

Fig. 4. Ultrastructure of cyst, subdivided in compartments. The thick outer wall is nearly dissolved at the periphery, $\mathrm{c}=$ cyst wall, $\mathrm{n}=$ nucleus, $\mathrm{g}=$ dense granules, $\mathrm{A}=10 \mu \mathrm{m}$ 
These small lesions showed only slight macroscopical changes of the pseudobranch organ, perhaps a slightly pale colouration. It was in these lesions that the convoluted gill filaments were partly destroyed and replaced by numerous cysts. Each cyst contained up to 40 nuclei (Fig. 3). On the periphery of the tumours the cysts remained intact, whereas in the centre, many of the cyst walls were distupted, releasing masses of free floating cells, and clusters of various blood cell types were scattered all around. Intact cysts were invariably subdivided into 2,4 or 6 compartments, both symmetrical and asymmetrical. Sometimes the nuclei of the cysts were arranged in a single layer forming a sphere filled with cytoplasm (Fig. 3).The nuclei of the cells were pale, each with a dark staining nucleolus. Released cells were either uni- or multinucleated with up to 8 nuclei. They had a light cytoplasmic rim enclosing a pale nucleus with a small distinct nucleolus.

The ultrastructure of the cysts was enclosed by a thick outer wall consisting of approximately ten layers, which were well differentiated with the PTA stain and most likely of mucopolysaccharide content. Where the cysts were divided into compartments the outer layers had disintegrated and the cytoplasm appeared amorphous, containing no cell organelles apart from a few membrane-bound electron dense granules (Fig. 4).

Similar cysts to those described were found in inflammatory lesions on the caudal peduncle over the lateral line. These lesions appeared as slight reddish swellings covered by a normal epidermis; less frequently, an ulcer was present.

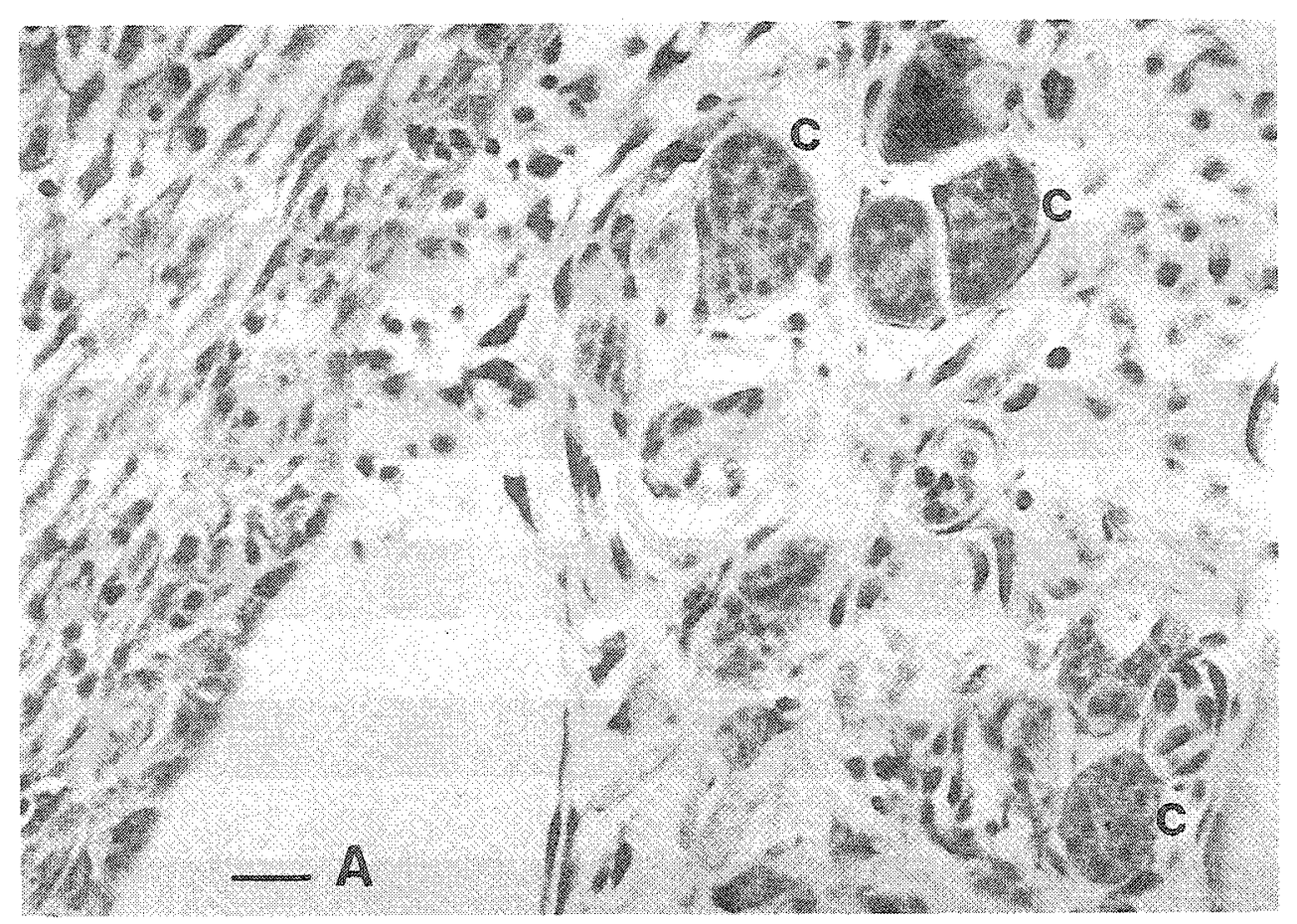

Fig. 5. Cysts at the caudal peduncle in the inflammatory connective tissue. $c=c y s t s, A=10 \mu \mathrm{m}$, haematoxylin-eosin stained 
The inflammation infiltrated tissues as far as the bone. Cysts occurring individually or in clusters were scattered throughout these inflammed areas. Many of these cysts had disrupted outer walls and were empty. Multinucleated and uni-nucleated cells from the cysts were interspersed and sometimes surrounded by fibroblasts, forming granulomas. A typical tumorous structure as seen in the pseudobranchial tumours was absent (Fig. 5).

\section{Multinucleated stages and tumorous growth}

A further stage of the pseudobranchial tumours involved a swelling surrounding the pseudobranch organ associated with massive inflammation. The overlaying epidermis appeared spongiotic, infiltrated with blood cells, and in some areas there was evidence of necrosis. This stage of tumour was characterized by the presence of disrupted cysts and masses of multinucleated cells located just along the inner side of the fibrous capsule surrounding the pseudobranch organ. From the periphery to the centre of the tumour the number of nuclei in each cell decreased to the typical uni-nucleated " $X$-cell" type (Fig. 6). The multinucleated cells were mainly surrounded by fibroblasts and rarely floating freely in interstitial fluid. In some areas, uni-nucleated cells not enclosed in envelope-cells were destroyed by phagocytic action (Fig.7). Central areas showed a tumorous arrangement situated along fibrous septae extending from the periphery inwards.

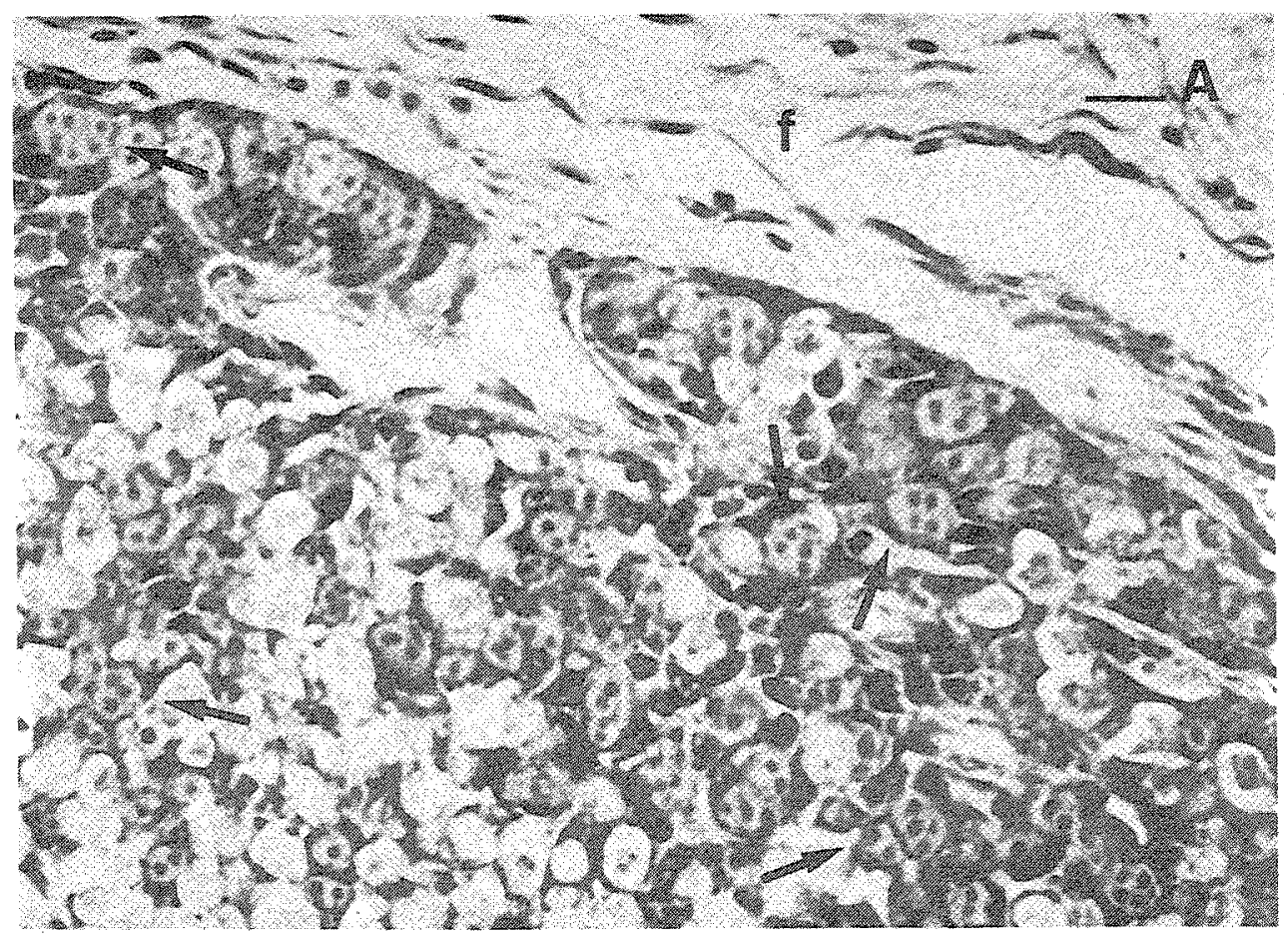

Fig. 6. Multinucleated cells along the inner side of the tibrous capsule surrounding the pseudobranch organ. Cells with decreasing number of nuclei down to uni-nucleated " $\mathrm{X}$-cells". Arrows indicating multinucleated " $\mathrm{X}$-cells", $\mathrm{f}=$ fibrous capsule, $\mathrm{A}=10 \mu \mathrm{m}$, haematoxylin-eosin stained 


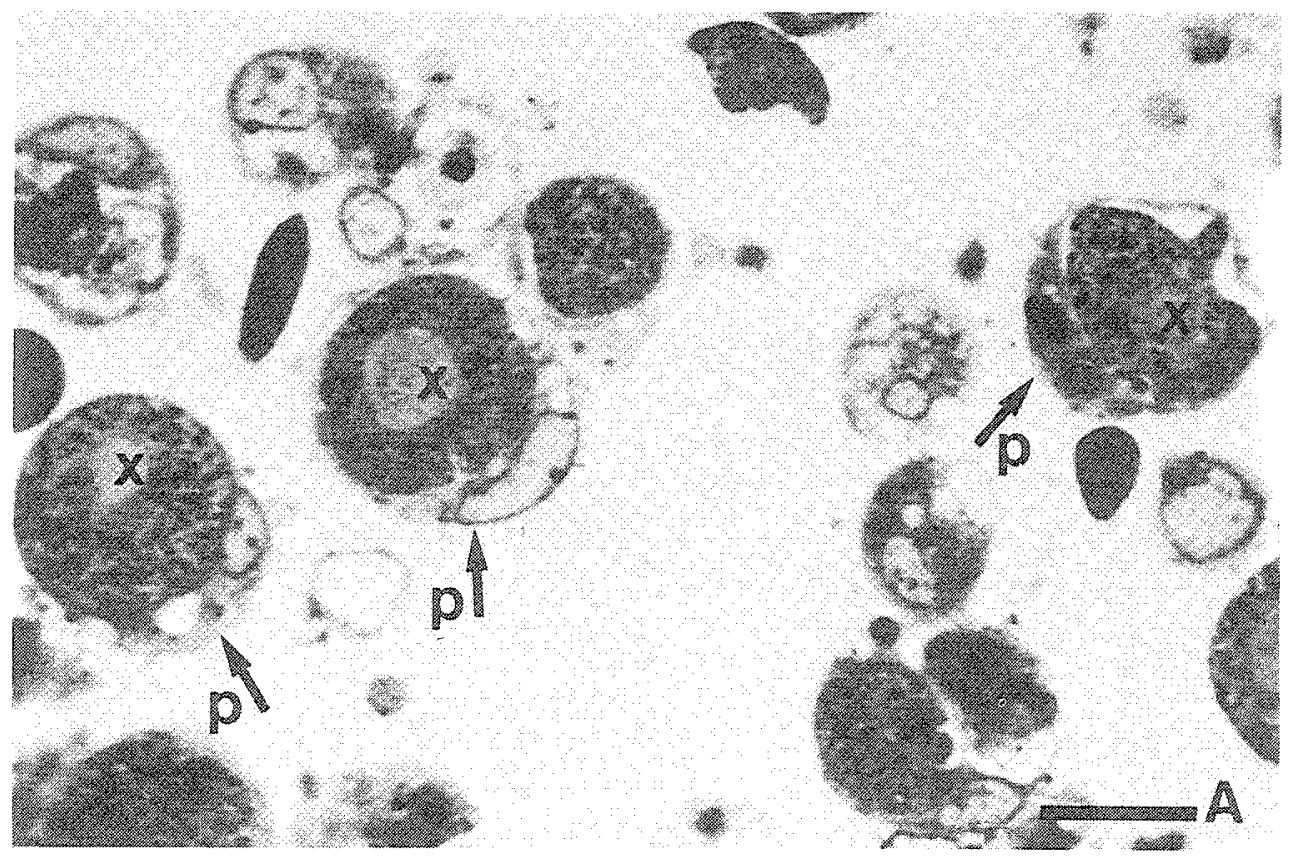

Fig. 7. Freely floating " $X$-cells" without envelope-cells, destroyed by phagocytic activities. $x=$ " $X$ cells", $\mathrm{p}=$ phagocytes indicated by arrows, $\mathrm{A}=10 \mu \mathrm{m}$, toluidine blue stained

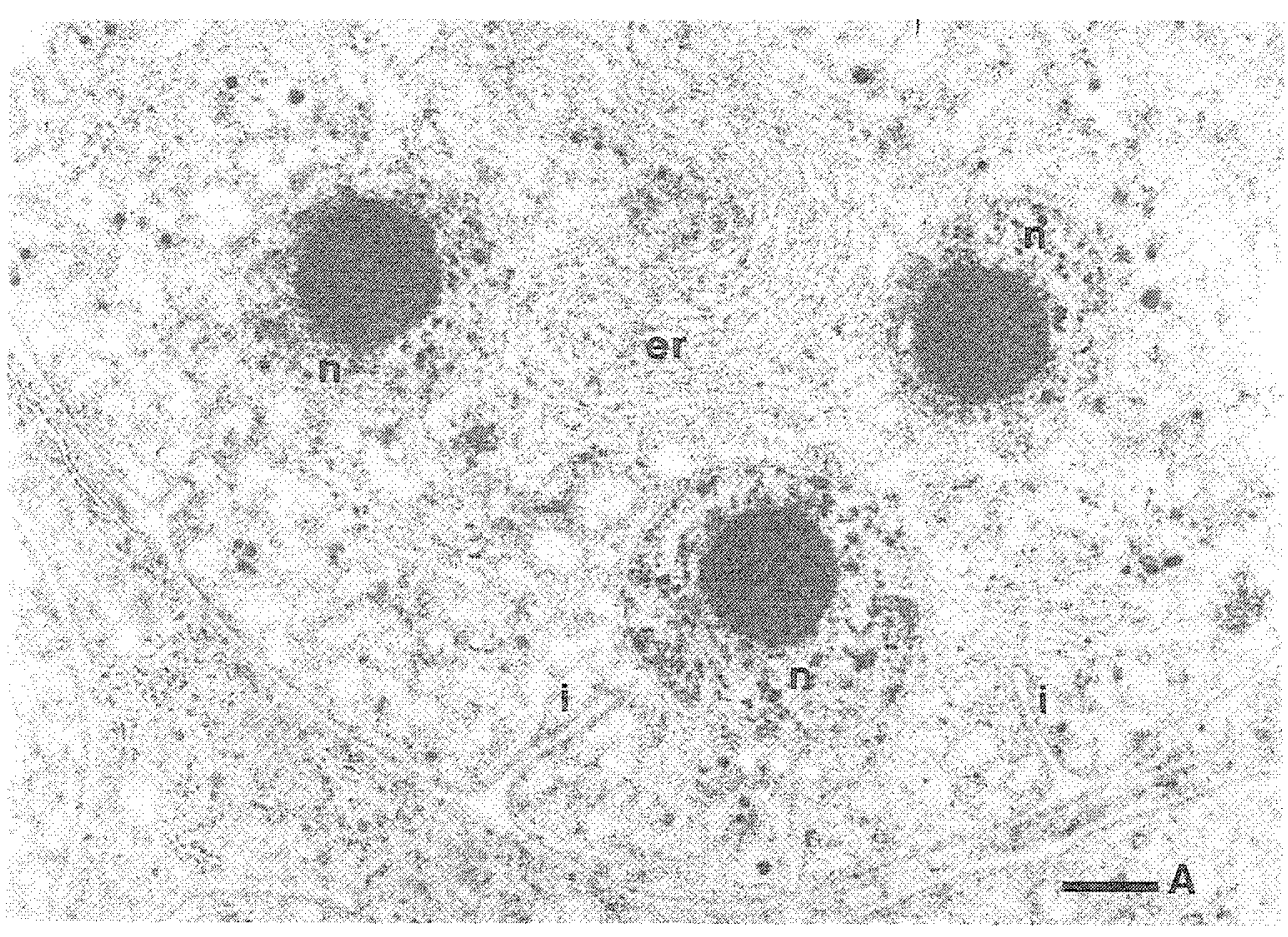

Fig. 8. Multinucleated "X-cell" with invaginations of the outer membrane, circular endoplasmatic reticulum and three nuclei. $\mathrm{n}=$ nucleus, er $=$ endoplasmatic reticulum, $\mathrm{i}=$ invaginations, $\mathrm{A}=$ 


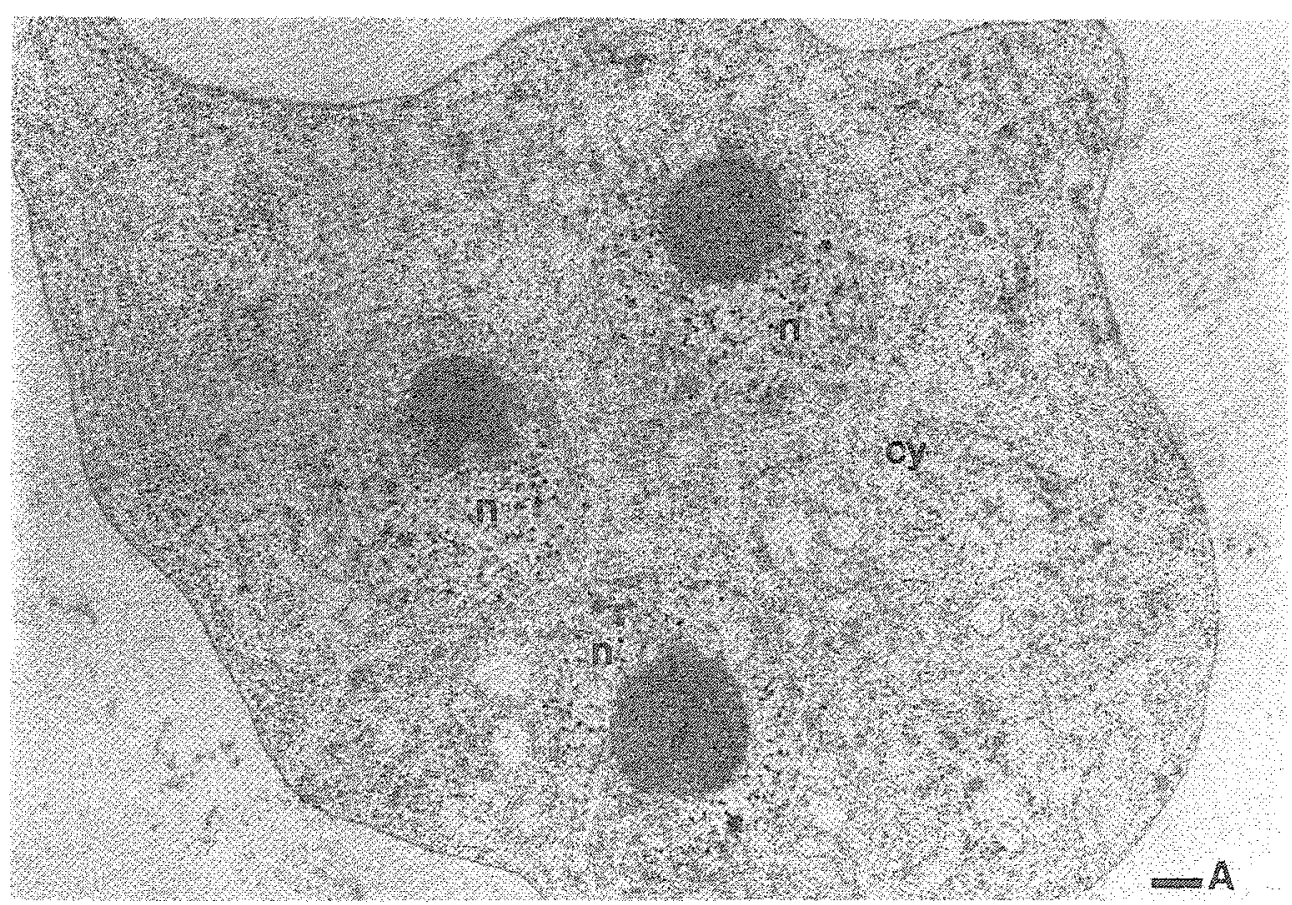

Fig. 9. Multinucleated, freely floating "X-cell" with three nuclei and a less differentiated cytoplasm. $n=$ nucleus, $c y=$ cytoplasm, $A=1 \mu \mathrm{m}$

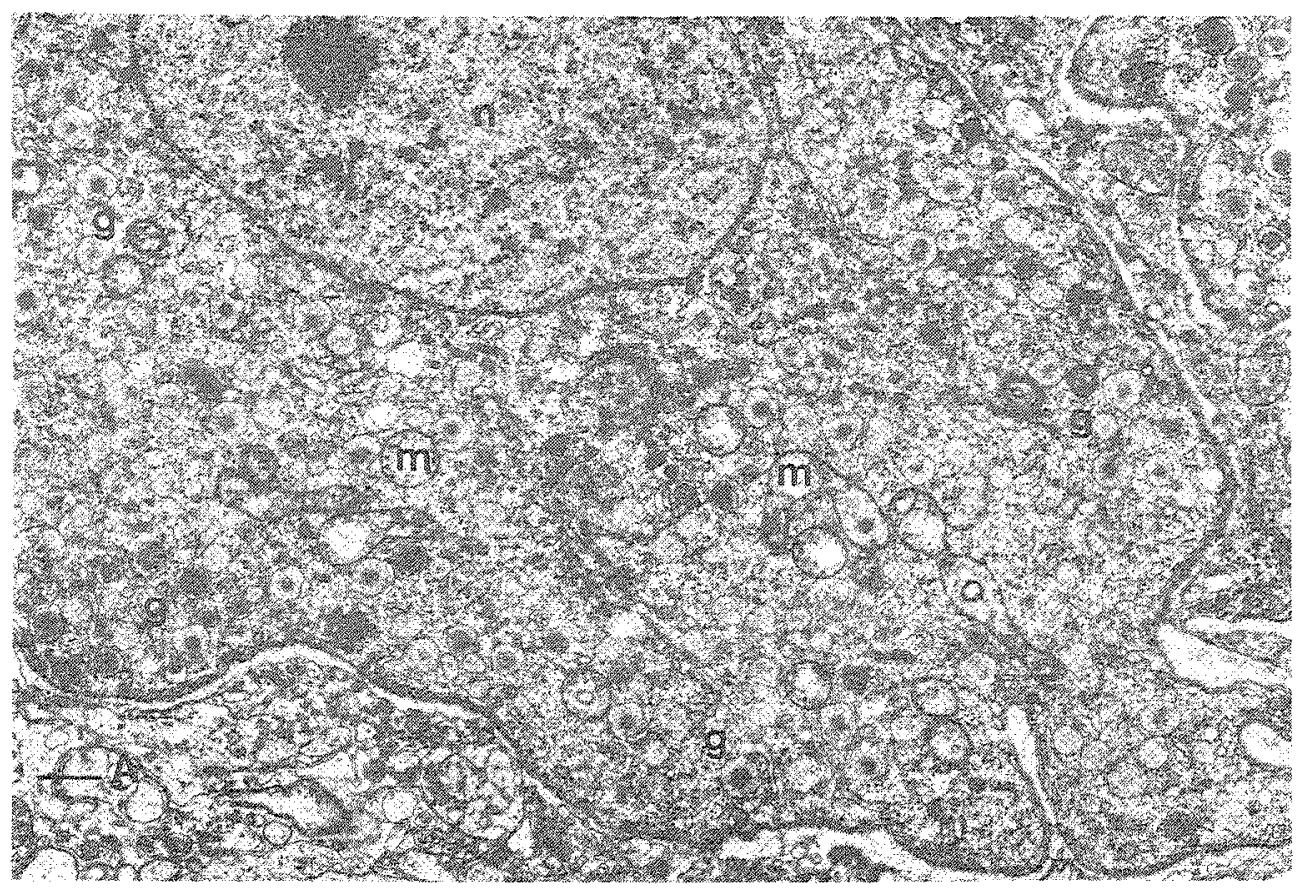

Fig. 10. Uni-nucleated "X-cell" with dense, granulated cytoplasm, pale nucleus and a prominent nucleolus. $\mathrm{n}=$ nucleus, $\mathrm{m}=$ mitochondria, $\mathrm{g}=$ membrane-bound dense granules, $\mathrm{A}=1 \mu \mathrm{m}$ 
Ultrastructural examination showed multi- and uni-nucleated cells to be coated with a thick outer membrane interspersed with invaginations. The cytoplasm was filled with masses of rough endoplasmatic reticulum sometimes in circles. Mitochondria were poorly developed. The nuclei showed finely dispersed chromatin and distinct nucleoli with eccentric pale areas (Fig. 8). The freely floating forms had frequently a less differentiated cytoplasm (Fig. 9).

\section{Tumours}

Masses of predominantly uni-nucleated "X-cells" were separated by fibrous septae into several compartments with blood vessels in parallel and branched patterns. " $X$ cells" located near these capillaries showed pale cytoplasm with few granules, while those further away from the capillaries showed dark, densely granulated cytoplasm enclosing a large pale nucleus with a distinct nucleolus (Fig. 10). Necrotic forms of "Xcells" with highly vacuolated or foamy cytoplasm were common in central areas. Double nucleated "X-cells" and mitotic figures near fibrous septae occurred in several tumours especially in the small tumours on gill filaments (Fig. 11).

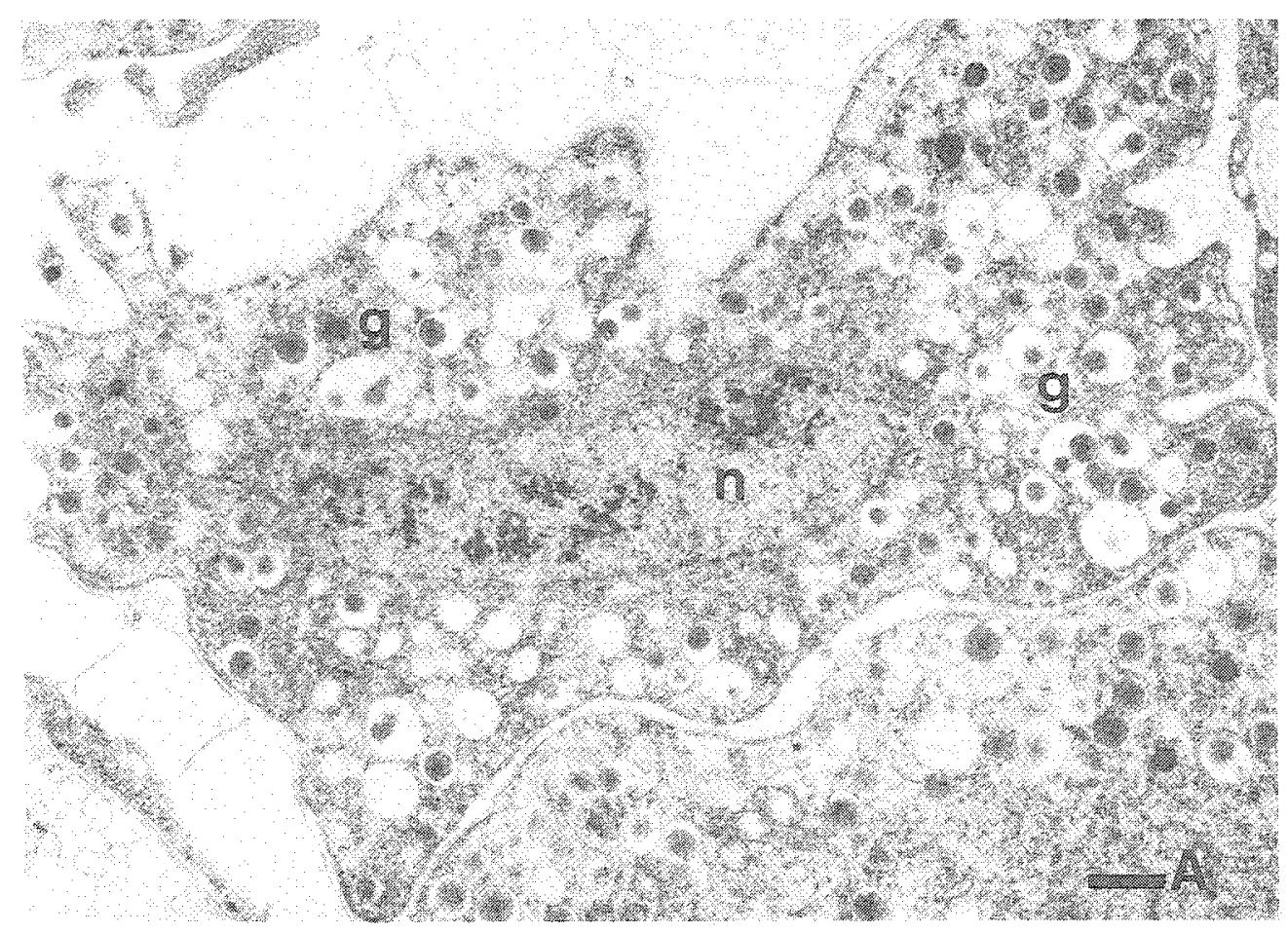

Fig. 11. Unimndeated " $X$-cell" in a tumour with dense, granulated cytoplasm and an elongated nucleus with condensed chromatin, possibly in prophase. $n=$ nucleus, $g=$ membrane-bound dense granules, $\mathrm{A}=1 \mu \mathrm{m}$ 


\section{DISCUSSION}

The investigated tumours in Atlantic cod (Gadus morhua) from the North Sea and the Baltic Sea are identical to those earlier described for the Atlantic (Peyron \& Thomas, 1929; Lange, 1973; Lange \& Johannessen, 1977; Morrison et al., 1979; Egidius et al., 1981) as well as for the Pacific (Alpers et al., 1977; Stich et al., 1976; McCain et al. 1976 1979; Wellings et al., 1977; Dawe, 1981). Most of these publications concentrate on the description of the common "X-cell" stage in pseudobranchial tumours. Besides this stage only Alpers et al. (1977) and Dawe (1981) described multinucleated cells as well as mitotic activities. As our investigation shows, these stages seem to be very important for clearing up the real character and origin of " $\mathrm{X}$-cells". The occurrence of cysts in the inflammed lesions associated with the pseudobranch organ and on the caudal peduncle, the multinucleated cells surrounding the early swellings of pseudobranch and the continuous transition from these early lesions to the well known tumorous structure with the uni-nucleated "X-cells", lead to the hypothesis that all these different cell types are successsive stages of an infective agent. This infective agent seems to be of protozoan origin and the earlier described typical "X-cells" seem to be a special stage in the life cycle of this organism.

From our observations of the different stages, infection could occur as follows: an unidentified infectious agent enters the host as a freely floating form of parasite via the epidermis, gills, lateral line or nose cavity. Possibly, because the organism has a high oxygen demand, it starts to develop and multiply in the pseudobranch organ, thus leading to the first visible lesion. The mature cysts undergo division and release uni- or multinucleated cells. These latter cells divide to form uni-nuclear cells, thus increasing the volume of " $\mathrm{X}$-cells" tenfold.

These "X-cells" show active mitosis and lead to tumorous growths around the pseudobranch organ or other infection sites. The early inflammatory reaction disappears when the tumorous structure has been formed. Possibly, the protozoa prevent phagocytosis by inducing extensive envelope-cell formation around themselves. Simultaneously, the host develops a fibrous network, subdividing masses of tumorous growth. This protective state may lead to a stalemate between the infectious agent and the host. A low level of nutrition may sustain the parasite at a diminishing rate, indicated by the degraded appearance of the majority of "X-cells".

Continuing this hypothesis, we suggest that the infective agent possibly uses the cod as a host for multiplication and propagation; it is unclear, however, in which way it enters and leaves the host.

There have been reports of "X-cells" occurring in lesions of several fish species, especially in Pacific flatfish papillomas (Wellings et al., 1965). The cells are suspected of being either of protozoan origin or of being transformed fish cells (Wellings et al., 1977; Peters et al., 1978, 1981 and Dawe, 1981). However, in contrast to the pseudobranchial tumours in cod, cysts and multinucleated cells have never been seen. Moreover, investigations using autoradiographic techniques to demonstrate mitotic activities have yielded negative results (Wellings et al. 1976; Kranz et al., 1980). It would seem that the "X-cells" in Pacific flatfish papillomas are possibly not identical with those in pseudobranchial tumours.

The only "X-cell"-like forms discovered in Atlantic waters, besides those in gadids, 
were found in dab (Limanda limanda) where they cause an inflammatory lesion in the subcutaneous tissue (Watermann, 1982). Apart from some similarities of cell type, it is now unclear whether the cells in the dab condition are identical or even related to those in the cod.

In contrast, the " $\mathrm{X}$-cells" in cod show significant evidence of protozoan origin and the tumour formations are pseudotumours. It seems more than unlikely that endocrine tumours (Egidius et al., 1981) or virally transformed fish cells (Peters et al., 1981) could show the different cell stages as described above. Furthermore, there are several similarities on the cell level with protozoa and especially with some amoebae. Circular patterns of endoplasmatic reticulum occur frequently in amoebae as described by Miller et al. (1961). The deep invaginations are also well known in amoeba where they serve for pinocytosis (Brandt \& Pappas, 1960).

Dawe (1981) suggested that the parasites have a striking similarity with the Hartmannelidae Dobellina mesnili as described by Bishop \& Tate (1939). Our observations differ because of the presence of cysts, which show cytoplasm division as described for Schizamoeba salmonis by Davis (1926). Several stages in the life cycle of this amoeba have striking similarities with the "X-cells" in pseudobranchial tumours. But there is only little information about this amoeba, and its taxonomic status is still unclear (Noble \& Noble, 1966).

Acknowledgements. Special thanks to Dr. D. Bucke for critically reviewing this manuscript. We also thank Mrs. W. Schmidt for the photographs, and Mrs. H. Rennert for technical assistance.

\section{LITERATURE CITED}

Alpers, C. E., McCain, B. B., Myers, M. S., Wellings, S. R., Poore, M., Bagshaw, J. \& Dawe, C. J., 1977. Pathologic anatomy of pseudobranch tumours in Pacific cod, Gadus macrocephalus. $-J$. natn. Cancer Inst. 59, 2.

Bishop, A. \& Tate, P., 1939. The morphology and systematic position of Dobellina mesnili nov. gen. (Entamoeba mesnili Keilin, 1917). - Parasitology 31, 501-511.

Brandt, P. W. \& Pappas, G. D., 1960. An electron microscopic study of pinocytosis in ameba. - J. biophys. biochem. Cytol. 8, 675-687.

Davis, H. S., 1926. Schizamoeba salmonis, a new ameba parasitic in salmonid fishes, - Bull. Bur. Fish., Wash. 42, 1-8.

Dawe, C. J, 1981. Polyoma tumors in mice and $\mathrm{x}$-cell tumors in fish viewed through telescope and microscope, - In: Phyletic approaches to cancer. Ed. by C. J. Dawe, J. C. Harshbarger, S. Kondo, T. Sugimura, \& S. Takayama. Japan Scient. Soc. Press, Tokyo, 19.

Egidius, E. D., Johannessen, J. V. \& Lange, E., 1981. Pseudobranchial tumours in Atlantic cod, Gadus morhua L., from the Barents Sea. - J. Fish Dis. 4, 527-532.

Kranz, H., Peters, N., Bresching, G. \& Stich, H. F., 1980. On cell kinetics in skin tumours of the Pacific English sole Parophrys vetulus Girard. - J. Fish Dis. 3, 125-132.

Lange, E., 1973. Carcinoid-like tumours in the pseudobranch of Gadus morhua. - Comp. Biochem. Physiol. 45A, 477-481.

Lange, E. \& Johannessen, J. V., 1977. Histochemical and ultrastructural studies of chemodectomalike tumours in the cod (Gadus morhua). - Lab. Invest. 37 (1), 96.

McCain, B. B., Myers, M. S., Gronlund, W. D., Wellings, S. R. \& Alpers, C. E., 1976. The frequency, distribution, and pathology of three diseases of demersal fishes in the Bering Sea. - J. Fish Biol. $12,267-276$.

McCain, B. B., Gronlund, W, D., Myers, M. S. \& Wellings, S. R., 1979. Tumours and microbial diseases of marine fishes in Alaskan waters. - J. Fish Dis. 2, 11-130. 
Miller, J. H., Swartzwelder, J. C. \& Deas, J. E., 1961. An electron microscopic study of entamoeba histolytica. - J. Parasit, 47, 577-587.

Morrison, C. M. Appy, R. G., Shum, G., Annand, C. \& Odense, P., 1979. Histology and the incidence of pseudobranch tumours in Atlantic cod (Gadus morhua) in Halifax Harbour. - C. M. - ICES/ E31.

Noble, E. R. \& Noble, G. A., 1966. Amebic parasites of fishes. - J. Protozool. 13, 478-480.

Peters, N., Peters, G., Stich, H. F., Acton, A. B. \& Bresching, G., 1978. On differences in skin tumours of Pacific and Atlantic flatfish. - J. Fish Dis. 1, 3-25.

Peters, N., Stich, H. F. \& Kranz, H., 1981. On the relationship between lymphocystis disease and Xcell papillomatosis of flatfish. - In: Phyletic approaches to cancer. Ed. by C. J. Dawe, J. C. Harshbarger, S. Kondo, T. Sugimura, \& S. Takayama. Japan Scient. Soc. Press, Tokyo, 111.

Peyron, A. \& Thomas, L., 1929. Contribution à l'étude des tumeurs du revêtement branchial chez les poissons. - Bull. Ass. fr. Etude Cancer 18, 825-827.

Stich, H. F., Acton, A. B. \& Forrester, C. R., 1976. Fish tumors and sublethal effects of pollutants. - J. Fish. Res. Bd Can. 33, 1993-2001.

Watermann, B., 1982. An unidentified cell type associated with an inflammatory condition of the subcutaneous connective tissue in dab (Limanda limanda). - J. Fish Dis. 5, 257-261.

Wellings, S. R. Chuinard, R. G. \& Bens, M., 1965. A comparative study of skin neoplasms in four species of pleuronectid fishes. - Ann. N. Y. Acad. Sci. 126, 479-501.

Wellings, S. R., McCain, B. B. \& Millers, B. S., 1976. Epidermal papillomas in Pleuronectidae of Puget Sound, Washington. - Prog. exp. Tumor Res, 20, 55-74.

Wellings, S. R., Alpers, C. E., McCain, B. B. \& Myers, M. S., 1977. Fish disease in the Bering Sea. Ann. N. Y. Acad. Sci. 298, 290-304. 